\title{
Implementasi Teknik P\&O Pada Optimisasi Daya Pengisian Baterai Dari Sel Surya
}

\author{
Rianda $^{1)}$, Hendro Cahyono ${ }^{2)}$ \\ Magister Teknik Elektro Universitas Tanjungpura Pontianak, \\ ${ }^{1)}$ Jurusan Teknik Elektro Politeknik Negeri Pontianak \\ ${ }^{2)}$ Jurusan Teknik Mesin Politeknik Negeri Pontianak \\ e-mail : rian2ty@yahoo.com ${ }^{1)}$,h3ndrock@gmail.com ${ }^{2)}$
}

\begin{abstract}
Pada sistem konversi pembangkit listrik tenaga surya, teknik MPPT merupakan suatu teori atau gagasan yang bertujuan menemukan cara bagaimana mendapatkan nilai puncak energi, atau daya untuk kuat penyinaran matahari yang berubah-ubah. Pada sistem pengisian baterai dari sel surya yang diusulkan, teknik $P \& O$ (perturb and observation) merupakan salah satu dari teknik MPPT, yang dipilih berdasarkan pertimbangan bahwa teknik ini memiliki algoritma sederhana dan mampu menjejak potensi daya maksimum dari sel surya. Bertitik tolak dari algoritma $P \& O$, disusun deskripsi lanjut untuk mendapatkan bentuk implementasi yang tepat pada bidang elektronika. Dari hasil deskripsi dan ketersediaan komponen lokal, dilakukan perancangan untuk memenuhi tujuan implementasi yang tepat. Rancangan sistem ini terdiri dari bagian- bagian yang saling mendukung dan bekerja sesuai dengan prinsip yang diinginkan. Setelah melalui proses perancangan dilanjutkan dengan pembuatan prototipe perangkat elektronika. Melalui percobaan berupa pengukuran dan pengujian diperoleh data, ketika dianalisa dapat dilihat pola dan karakter yang yang terlihat memenuhi kriteria rancangan. Realisasi sistem pengisian baterai dari sel surya ini terwujud tidak terlepas dari kendala dan proses perbaikan, meskipun demikian dapat dikatakan sistem memenuhi kriteria rancangan seperti biaya rendah, rugi-rugi konversi daya kurang dari $30 \%$ dan konverter daya bekerja dengan baik pada tiap kuat penyinaran yang berbeda.
\end{abstract}

Keywords- teknik MPPT, P\&O, implementasi dan perangkat elektronika.

\section{Pendahuluan}

Pemanfaatan energi terbarukan oleh pemerintah yang diterima masyarakat, diantaranya adalah energi matahari, mulai dari program penyediaan kelistrikan daerah terpencil yang menggunakan sel surya, sampai ke penerangan jalan umum di perkotaan. Penggunaan teknologi dalam hubungannya pemanfaatan energi matahari ini kian meluas, produk teknologi yang digunakan mulai dari sel surya, BCU (battery control unit) dan baterai merupakan sistem paket teknologi sel surya. Fabrikasi sel surya dilakukan oleh fabrik semikonduktor, dapat dilakukan oleh beberapa negara tertentu saja sedangkan BCU di produksi oleh banyak negara produsen elektronik.

Penggunaan baterai pada sistem paket energi surya sebagai penyimpan energi sementara, dimana diketahui energi listrik yang dikonversi oleh sel surya sangat tergantung dari fluktuasi kuat penyinaran yang diterima dari matahari. Energi yang akan disimpan di bateri ini merupakan nilai rata- rata dari jumlah total variasi penyinaran yang diterima.

Baterai dengan tegangan kerja sel $12 \mathrm{~V}$, pada saat muatan baterai masih rendah mempunyai tegangan sekitar 10,8 volt dapat menarik arus pengisian cukup tinggi hingga 25\% dari kapasitas Ah nominal [1], kemudian berangsur turun hingga muatan penuh, jika muatan sudah penuh, arus yang mengalir ke baterai bisa mencapai 0 (nol) ampere.

Salah satu fungsi yang dilakukan oleh BCU adalah pengisian baterai, merupakan proses yang yang dilakukan dengan memperhatikan beberapa hal yang berhubungan dengan keamanan, jenis penggunaan dan waktu hidup penggunaan baterai. Dengan menerapkan pengisian dengan metode tegangan konstan, penting untuk mengetahui jenis baterai dan tegangan set pengisian agar tidak terjadi pengisian berlebih yang dapat merusak sel baterai. Temperatur sekitar sangat mempengaruhi tegangan set pengisian, dimana temperatur rendah cenderung memerlukan tegangan pengisian lebih tinggi dan sebaliknya jika temperatur tinggi maka tegangan pengisian harus diturunkan.

Pada temperatur sekitar sebesar $25^{\circ} \mathrm{C}$ jenis baterai SLA (sealed lead acid) dapat diisi dengan tegangan paling tinggi sebesar 14 volt, sedangkan jenis sel basah sebesar 14,4 volt [1]. Dengan memperhatikan besar tegangan ini maka baterai dapat diisi dengan aman dari bahaya pengisian berlebih.

\section{Teori Dasar \\ 2.1 Sel Surya}

Suatu sel surya atau sel photo voltaic dapat mengubah energi surya yang diperoleh dari matahari menjadi energi listrik arus searah, hal ini dimungkinkan karena sel surya merupakan sambungan P-N material semikonduktor seperti sebuah dioda photo, yang dapat menghasilkan tegangan dan arus listrik jika terkena sinar matahari. Sel surya yang besar merupakan gabungan 
rangkaian kombinasi seri dan paralel sel dasar. Sel surya dapat diwakili oleh model listrik yang ditunjukkan pada Gambar 1.

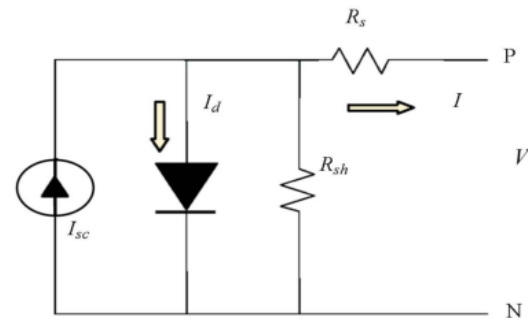

Gambar 1. Rangkaian setara dari sel surya atau model listrik sebuah sel surya [2]

Sel surya dengan tingkat penyerapan energi surya tertentu memiliki karakteristik yang seperti pada Gambar 2

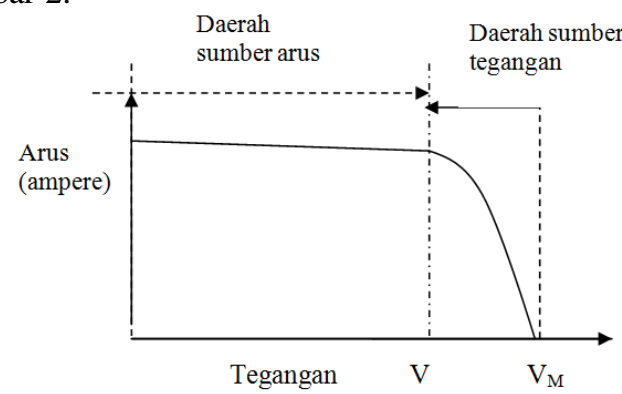

Gambar 2. Karakteristik sel surya.[2]

Karakteristik penting lain yang berpengaruh adalah pada Gambar 3, yang memberikan gambaran perubahan temperatur sekitar dan kenaikan temperatur saat beroperasi dapat menurunkan tegangan kerja pada sel surya.

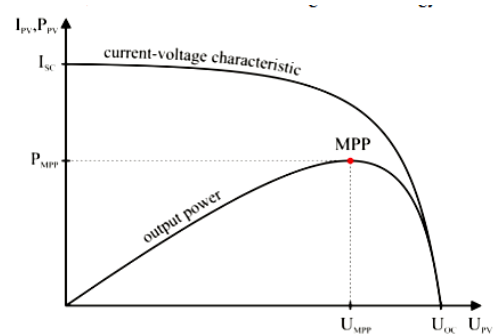

Gambar 3. Karakteristik serapan daya pada sel surya [2]

Temperatur yang makin tinggi membuat tegangan kerja sel surya makin rendah, hal ini membuat titik kerja $\mathrm{U}_{\mathrm{MPP}}$ berubah atau bergeser ke nilai yang lebih kecil.

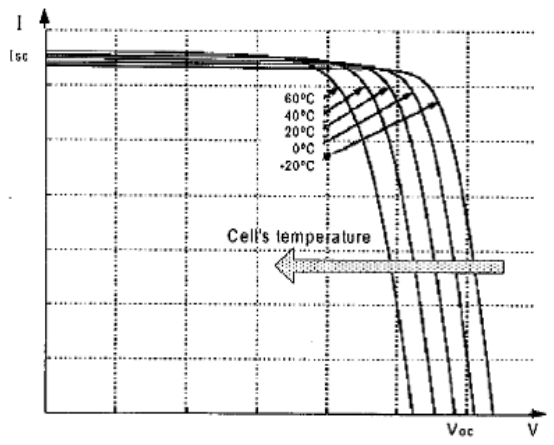

Gambar 4. Karakteristik perubahan tegangan keluaran sel surya sebagai akibat perubahan temperatur sekitar dan temperatur sel itu sendiri [5]

\subsection{Konsep MPPT}

Karakteristik arus - tegangan dari panel surya adalah tidak linier, dan daya yang dihasilkan memiliki pada titik operasi maksimum tertentu, yang disebut maximum power point ( MPP), seperti ditunjukkan pada Gambar 3, untuk menghasilkan energi sebanyak mungkin pada kondisi operasi tertentu, panel surya harus beroperasi pada MPP (yang tercirikan dengan besar tegangan sel surya pada titik tersebut), yaitu energi harus dihasilkan tertinggi pada potensi daya yang tersedia. Karena MPP berubah dengan radiasi surya dan suhu sekitar, sebuah algoritma yang melakukan maximum power point tracking diperlukan. Idealnya, dengan menggunakan sebuah algoritma MPPT, keluaran daya panel surya dimaksimalkan terlepas dari radiasi matahari, suhu lingkungan, dan berbagai kondisi atmosfer. sebagai akibatnya, efisiensi pembangkitan listrik, serta jumlah energi yang dihasilkan meningkat. Dari sekian banyak metode untuk melacak titik daya maksimum, tetapi hanya tiga metode berikut ini yang paling banyak digunakan [2] dan akan menjadi referensi dari penelitian, yaitu:

- Metoda tegangan konstan ( CV )

- Metoda mengusik dan amati ( P \& O )

- Metoda konduktansi inkremental ( INC)

Metode CV bergantung hanya pada fakta bahwa rasio tegangan pada titik MPP ( $\left.\mathrm{U}_{\mathrm{MPP}}\right)$ dan tegangan beban kosong $\left(\mathrm{U}_{\mathrm{OC}}\right)$ hampir konstan, yaitu $\mathrm{U}_{\mathrm{MPP}} / \mathrm{U}_{\mathrm{OC}} \approx$ k. Meskipun algoritma CV sangat sederhana, sulit untuk memilih nilai optimal untuk k konstan. Menurut [3] nilai optimal $\mathrm{k}$ adalah dalam kisaran dari $73 \%$ menjadi $80 \%$. Permasalahan lain dengan metode ini adalah bahwa k sebenarnya tergantung pada suhu dan radiasi, dan dapat bervariasi sebanyak $8 \%$ atas seluruh rentang kondisi operasi

Metoda mengusik dan mengamati $(\mathrm{P} \& \mathrm{O})$ merupakan metode yang banyak digunakan, karena kesederhanaannya [3]. Dalam algoritma P\&O, tegangan panel surya diganggu (diusik) secara berkala (meningkat atau menurun), dan daya keluaran panel akan dipantau setelah setiap gangguan. Jika terjadi peningkatan daya output setelah adanya gangguan, berikutnya gangguan harus dilakukan dalam arah yang sama dengan sebelumnya. Jika daya menurun, gangguan tersebut harus dibuat dalam arah yang berlawanan. Algoritma akan terus melakukan gangguan (perturb) dan mengamati (observation) tegangan panel surya bahkan setelah MPP telah tercapai. Dengan demikian, setelah MPP tercapai, tegangan panel surya akan berosilasi di sekitar titik daya maksimum. Osilasi ini akan mengakibatkan kerugian daya yang tidak diinginkan, dan mengurangi efisiensi sistem panel surya. Osilasi dapat diminimalisir dengan mengurangi ukuran langkah gangguan. Namun, pengurangan ukuran langkah akan memperlambat MPPT.

Keterbatasan lain dari algoritma $\mathrm{P} \& \mathrm{O}$ muncul selama tingkat penyinaran surya (insolation) rendah, ketika kurva daya keluaran panel cenderung datar. Hal ini membuat sulit untuk algoritma untuk membedakan lokasi MPP , karena perubahan keluaran daya kecil 
sehubungan dengan perubahan tegangan. Juga, dalam kasus kondisi atmosfer yang berubah dengan cepat (misalnya awan berpindah cepat), algoritma $\mathrm{P} \& \mathrm{O}$ akan menyimpang dari MPP sampai perubahan ke bawah melambat. Hal ini karena algoritma P\&O mengasumsikan bahwa perubahan daya PV adalah hasil dari hanya gangguan tegangan panel surya.

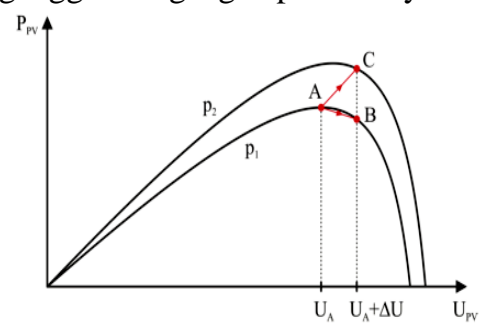

Gambar 5. Ilustrasi algoritma $\mathrm{P} \& \mathrm{O}$ pada saat perubahan kondisi atmosfer cepat [2]

Flow chart /diagram alir dari teknik $\mathrm{P} \& \mathrm{O}$ untuk konverter daya dengan kendali lebar pulsa (PWM = pulse width modulation) dapat dilihat pada gambar 6 . langkah awal dimulai dengan memberikan beban (gangguan) pada sel surya, besar nilai tegangan dan arus yang mengalir dari sel surya diamati dan diambil. Berikutnya dilakukan operasi perkalian pada kedua besaran yang diamati yang merupakan daya sel surya.

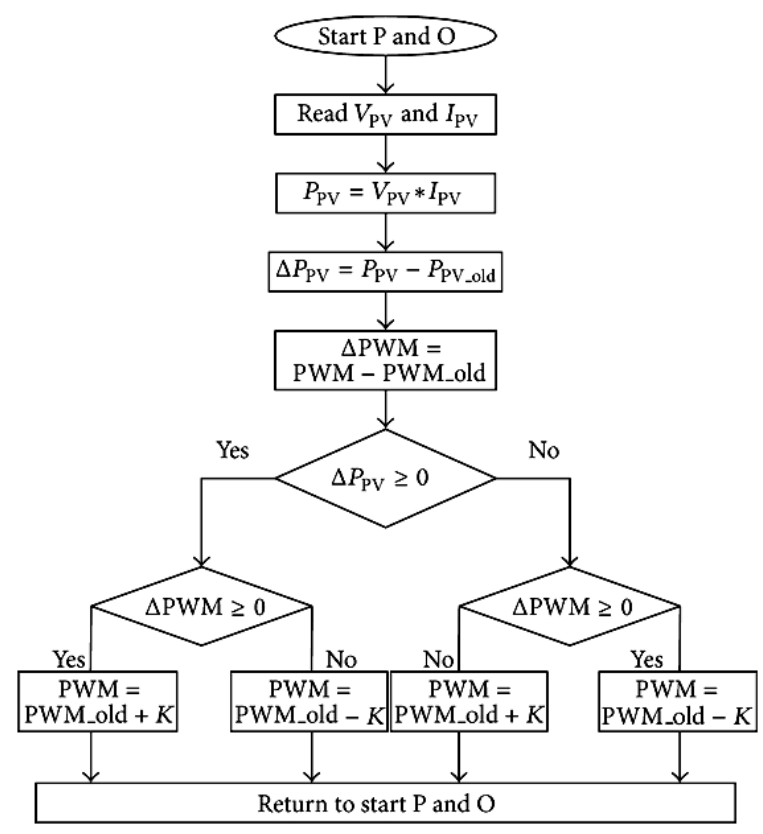

Gambar 6. Flow chart MPPT P\&O [3]

Untuk mengatasi kelemahan dari algoritma klasik $\mathrm{P} \& \mathrm{O}$, kita akan mencoba mengenal algoritma konduktansi inkremental (INC). Berbeda dengan algoritma $\mathrm{P} \& \mathrm{O}$, algoritma ini akan selalu membandingkan tegangan panel PV dengan tegangan MPP dan tidak terombang-ambing di sekitar MPP. Oleh karena itu, lebih efisien daripada algoritma klasik $\mathrm{P} \& \mathrm{O}$ [12]. Metode konduktansi inkremental ini didasarkan pada kenyataan bahwa kemiringan kurva keluaran daya dari panel surya adalah sama nol pada titik kekuatan maksimal, seperti ditunjukkan pada Gambar 7.

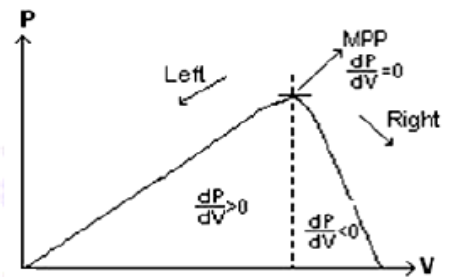

Gambar 7. Kurva daya maksimum sel surya [2]

$\frac{d P_{P V}}{d U_{P V}}=0 \quad$ Pada titik daya maksimum,

$\frac{d P_{P V}}{d U_{P V}}>0 \quad$ Pada titik kiri daya maksimum,

$\frac{d P_{P V}}{d U_{P V}}<0 \quad$ Pada titik kanan daya maksimum.

Karena daya keluaran panel $\mathrm{P}_{\mathrm{V}}$ merupakan hasil tegangan keluaran sel surya, $\mathrm{U}_{\mathrm{PV}}$, dan arus keluaran, $\mathrm{I}_{\mathrm{PV}}$, maka:

$\frac{d P_{P V}}{d U_{P V}}=\frac{d\left(U_{P V} I_{P V}\right)}{d U_{P V}}=I_{P V}+U_{P V} \frac{d I_{P V}}{d U_{P V}} \cong I_{P V} U_{P V} \frac{\Delta I_{P V}}{\Delta U_{P V}} .$. (2)

Langkah tetap algoritma MPPT INC dasar didasarkan pada persamaan (2.4), dan flowchart untuk algoritma ditunjukkan pada Gambar 2.9. Dalam Gambar 8. $\mathrm{U}_{\mathrm{k}}$ dan $\mathrm{I}_{\mathrm{k}}$ adalah $\mathrm{k}$-th sampel dari tegangan panel, $\mathrm{U}_{\mathrm{PV}}$, dan arus panel, $\mathrm{I}_{\mathrm{PV}}$, masing-masing. $\mathrm{U}_{\mathrm{r}}$ adalah setpoint tegangan panel surya, dan $\Delta \mathrm{Ur}$ merupakan perubahan langkah setpoint (tetap).

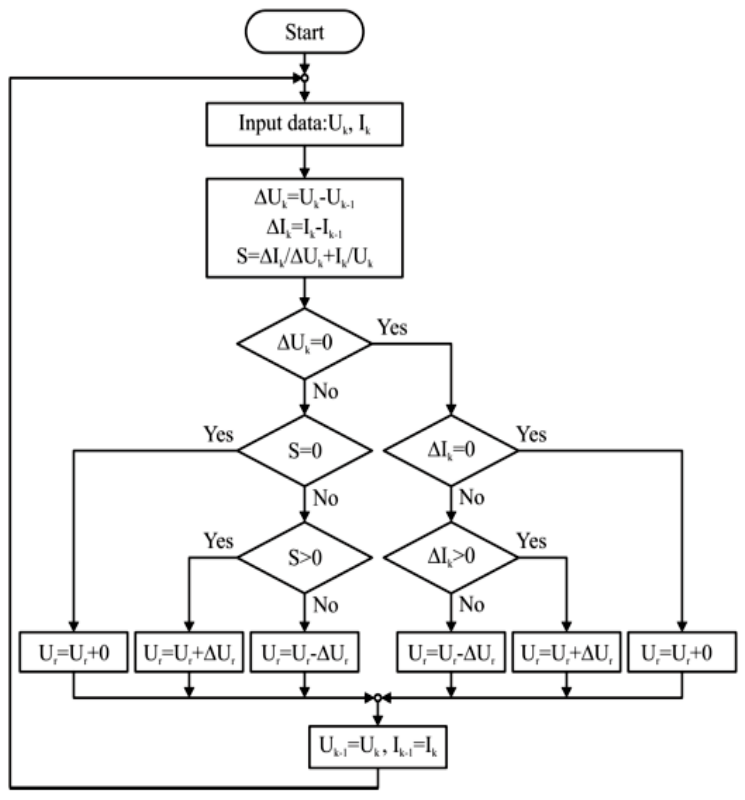

Gambar 8. Flow chart konduktansi inkremental [3]

\subsection{Konverter DC ke DC}

Konverter DC ke DC merupakan suatu sistem yang melakukan pengubahan tegangan masukan searah, menjadi tegangan keluaran searah dengan nilai tegangan yang lebih rendah, lebih tinggi atau mengubah polaritas tegangan.

Konverter ini melakukan pengubahan tegangan dengan mode saklar. Salah satu jenis konverter DC ke DC ini adalah konverter Buck, yang melakukan konversi dengan hasil tegangan keluaran lebih rendah dari 
tegangan masukan. Bentuk rangkaian dasar konverter Buck dapat dilihat pada gambar 9.

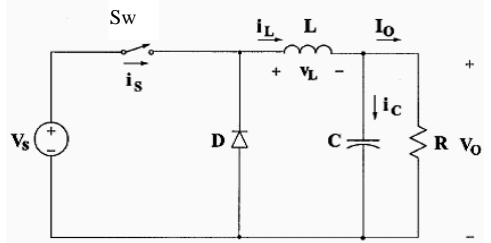

Gambar 9. Rangkaian dasar konverter Buck [13]

$\mathrm{S}_{\mathrm{W}}$ merupakan komponen elektronik utama (seperti; transistor) yang dapat dikendalikan sesuai dengan kecepatan on/off yang diinginkan. D adalah dioda yang juga dapat mengalirkan arus hanya pada satu arah. L (induktor) dan $\mathrm{C}$ (kapasitor) merupakan komponen pasif yang melakukan proses filter pada keluaran arus dan tegangan hasil pensaklaran $\mathrm{S}_{\mathrm{W}}$, sehingga dapat diperoleh tegangan dan arus keluaran searah yang lebih rata.

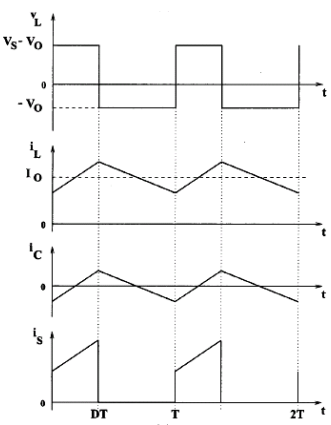

Gambar 10. Bentuk gelombang pada rangkaian dasar konverter Buck [13]

2.4 Diagram Blok Rancangan Sistem BCU

Diagram blok rancangan sistem BCU berbasis sistem MPPT dapat dilihat pada Gambar 2.21, terdiri dari empat blok utama. Fokus dari penelitian terletak pada blok konverter DC ke DC dan kontrol berbasis MPPT. Tipe konverter yang dipilih adalah Buck konverter, dengan pertimbangan bahwa tegangan sel surya lebih tinggi dari tegangan baterai.

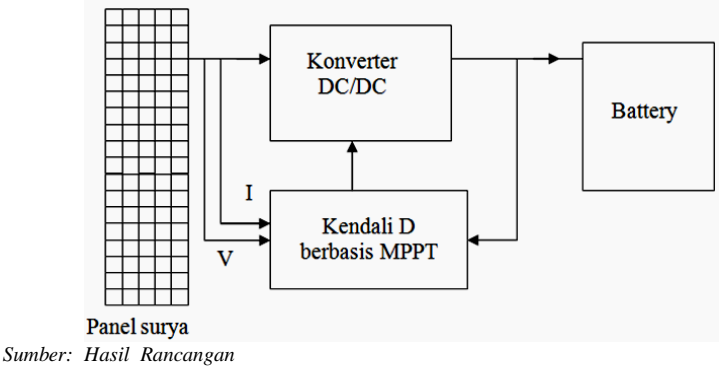

Gambar 11.Diagram blok rancangan sistem BCU

Kendali rasio D untuk harus memenuhi kriteria MPPT, dengan demikian proses pengendalian konverter akan menghasilkan puncak daya maksimum untuk setiap potensi yang ada pada panel surya.

\subsection{Algoritma MPPT yang Diusulkan.}

Mengacu kepada algoritma $\mathrm{P} \& \mathrm{O}$ yaitu proses mengusik dan mengamati, maka dapat disusun deskripsi urutan kerja rangkaian elektronika sebagai berikut;

1. Menghidupkan daya sistem
2. Mulai mengusik pada nilai acuan maksimum

3. Mengamati arus dan tegangan dari sel surya

4. Proses perkalian arus dan tegangan

5. Tahan pada titik maksimum

6. Berikan nilai ini sebagai acuan daya maksimum sementara tahan selama $t_{\mathrm{X}}$

7. Kembali ke langkah $1 \mathrm{~s} / \mathrm{d} 6$

Langkah pengendalian dari 1 sampai 6 dilakukan secara periodik seperti pada Gambar 12. Reaksi yang terjadi pada saat proses mengganggu (perturb) akan mengikuti bentuk kurva seperti pada Gambar 12, dimana hasil perkalian arus dan tegangan akan menghasilkan titik tertinggi dan ditahan selama langkah 6. Langkah hasil gangguan ini akan digunakan sebagai nilai acuan potensi daya pada sel surya.

Langkah $1 \mathrm{~s} / \mathrm{d} 5$ dilakukan memerlukan waktu tertentu untuk mendapatkan nilai cuplik potensi energi sel surya yang valid, semakin cepat semakin baik tetapi dengan kemampuan mendeteteksi daya dengan benar. Sedangkan langkah 6 dapat diatur secara

praktis berdasarkan hasil pengamatan kecepatan perubahan kuat penyinaran surya.

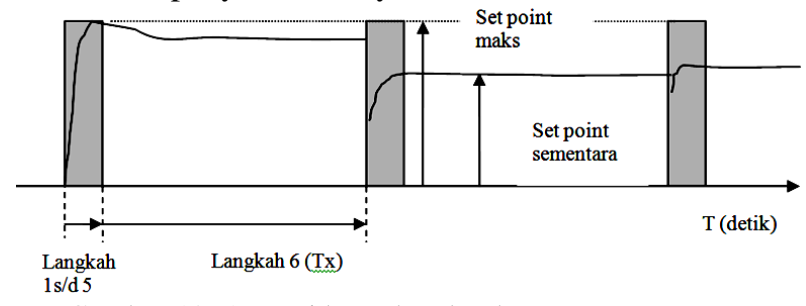

Gambar 12. Asumsi bentuk gelombang gangguan kontroler MPPT secara periodik [13]

2.6 Rancangan Blok Diagram Sistem Konverter Daya Berbasis MPPT.

Rancangan sistem yang dibangun seperti pada Gambar.13, mempunyai rangkaian pengali (multiplier) yang akan diterapkan sebagai pengolah perkalian arus dan tegangan yang berasal dari sel surya. Saklar SC1 dan SC2 bekerja untuk menghubungkan keluaran multiplier dan setpoint (nilai mengusik adalah nilai sebesar daya maksimal suplai sel surya) ke blok Sample and hold circuit. Kedua saklar secara periodik bekerja bergantian dan diatur oleh sebuah rangkaian timing circuit.

Asumsi selama proses mengusik, sel surya akan dihubungkan ke baterai dengan daya beban maksimal yang lebih besar dari daya sel surya, hal ini dimaksudkan untuk mendapatkan potensi daya sel surya maksimum, informasi daya maksimal ini diperoleh dari nilai setpoint. Selama proses ini daya tidak di transfer ke beban tiruan (dummy load), tetapi di salurkan ke baterai sehingga secara teori tidak ada daya hilang selama proses mengusik.

Rangkaian sample and hold bekerja menyimpan data sampling selama proses mengamati akan dipulihkan kembali saat proses mengusik dilakukan. Blok rangkaian batas tegangan maksimal berfungsi sebagai pengaman tegangan lebih keluaran yang akan membuat rangkaian kendali PWM berhenti bekerja jika tegangan maksimal bateri sudah tercapai. 


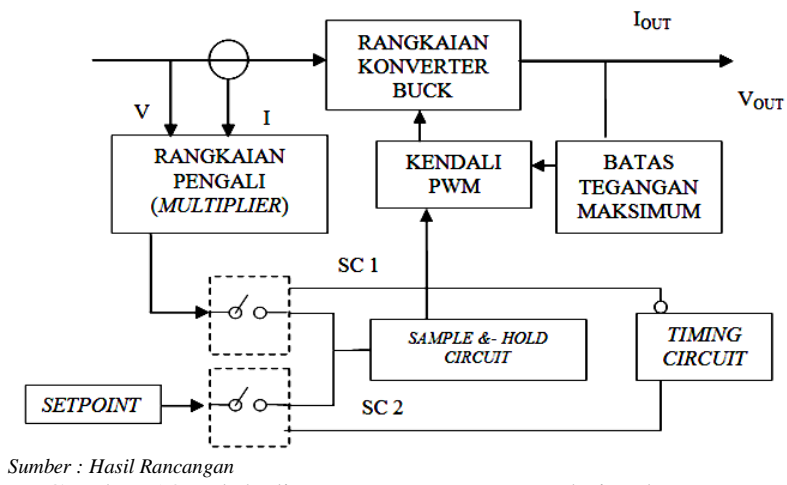

Gambar 13. Blok diagram rancangan rangkaian konverter berbasis MPPT

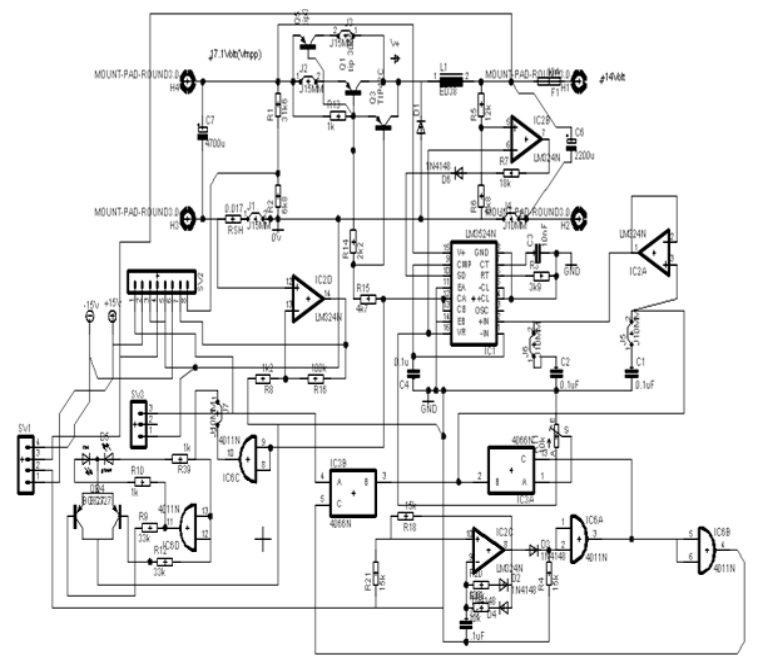

Sumber : Hasil Rancangan

Gambar 14. Rancangan rangkaian lengkap konverter Buck, (multiplier digambarkan hanya blok pin saja)

\section{Hasil Pengukuran dan Analisis}

3.1 Pengamatan Karakteristik Kendali VO $=[\mathrm{f}(\mathrm{D})]$

Hasil pengamatan dari seksi 3.5, dapat dilihat pada tabel.1, pengukuran diambil dengan mengatur lebar pulsa dengan pengamatan gambar osiloskop pada Gambar 16.

Pengamatan dilakukan dengan bereferensi kepada rangkaian pengukuran pada Gambar 14.

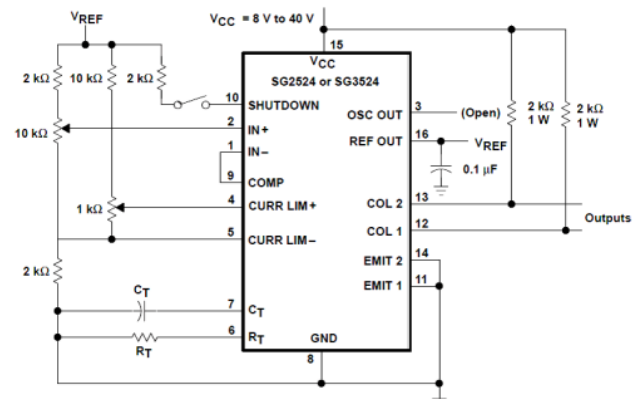

Sumber : Hasil Rancangan

Gambar . 15, Rangkaian pengujian kendali PWM IC SG 3524
Tabel.1 Pengukuran $\mathrm{V}_{\mathrm{O}}=[\mathrm{f}(\mathrm{D})]$.

\begin{tabular}{ccc}
\hline $\mathrm{D}$ & $\mathrm{Vo}$ & keterangan \\
\hline 0 & 0 & $\mathrm{D}=\mathrm{t}_{\mathrm{ON}} / \mathrm{T}$ \\
\hline 0.1 & 1.36 & \\
\hline 0.2 & 2.56 & $\mathrm{VO}=\mathrm{D}^{*} \mathrm{~V}_{\mathrm{M}}$ \\
\hline 0.3 & 3.68 & $\mathrm{~V}_{\mathrm{M}}=12.4$ Volt \\
\hline 0.4 & 4.83 & \\
\hline 0.5 & 5.97 & \\
\hline 0.6 & 7.09 & \\
\hline 0.7 & 8.118 & \\
\hline 0.8 & 9.44 & \\
\hline 0.9 & 10.6 & \\
\hline
\end{tabular}

Pengaturan lebar pulsa dilakukan dengan mengatur potensimeter $10 \mathrm{~K}$, sehingga tegangan pada pin 2 IC akan turun atau naik. Naiknya tegangan pada pin 2, akan menghasilkan pulsa keluaran lebih lebar, demikian sebaliknya. Dengan menjaga tegangan tetap akan diperoleh lebar pulsa yang tetap.

Hasil pengukuran tegangan rata-rata dicatat dan gambar tampilan bentuk gelombang akan dicetak, sesuai dengan tampilan yang nampak pada layar osiloskop. Gambar beberapa bentuk gelombang yang diamati berdasarkan seksi 3.5, sesuai dengan lebar pulsa yang diinginkan dapat dilihat pada Gambar 15.

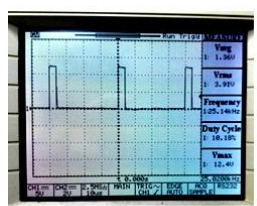

(a)

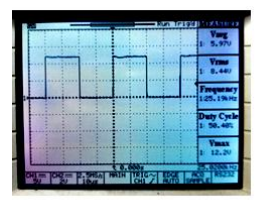

(d)

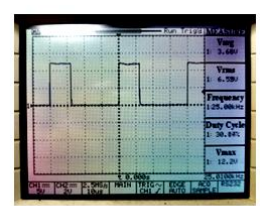

(b)

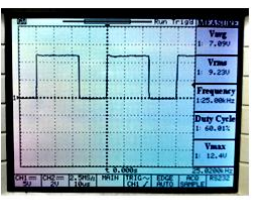

(e)

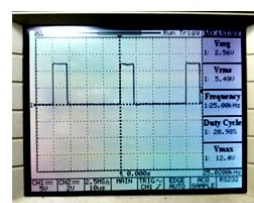

(c)

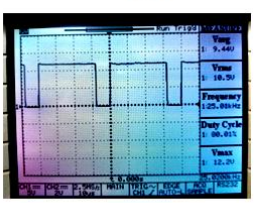

(f)
Gambar 16. Hasil pengamatan gelombang PWM

(a) $\mathrm{D}=10 \%$, (b) $\mathrm{D}=20 \%$, (c) $\mathrm{D}=30 \%$, (d) $\mathrm{D}=50 \%$, (e) $\mathrm{D}=60 \%$, dan (f) untuk $\mathrm{D}=80 \%$.

3.2 Pengujian Modul Sistem Pengisian baterai Berbeban Resistansi (Lampu) dengan Sumber DC konstan.

Pengujian prototipe rangkaian dari percobaan Gambar 17 dapat dilihat pada Tabel 2.

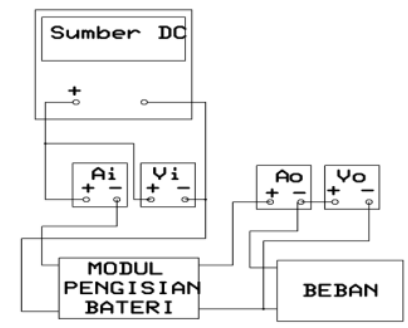

Gambar 17. Rangkaian pengukuran dan pengujian sistem pengisian bateri berbasis MPPT P\&O yang direncanakan. 
Tabel 2. Pengukuran modul pengisian baterai dalam keadaan berbeban

\begin{tabular}{rrrrrccc}
\hline No & $\mathrm{I}_{\mathrm{O}}(\mathrm{A})$ & $\mathrm{V}_{\mathrm{O}}($ Volt $)$ & $\mathrm{I}_{\mathrm{IN}}(\mathrm{A})$ & $\mathrm{V}_{\mathrm{IN}}($ Volt $)$ & P $_{\text {OUT }}$ & $\mathrm{P}_{\mathrm{IN}}$ & \multicolumn{5}{l}{} \\
\hline 1 & 1.02 & 14 & 1.03 & 18 & 14.28 & 18.54 & 77.02 \\
\hline 2 & 1.62 & 13.7 & 1.6 & 18 & 22.19 & 28.80 & 77.06 \\
\hline 3 & 2.13 & 13.6 & 2.09 & 18 & 28.97 & 37.62 & 77.00 \\
\hline 4 & 3 & 13.2 & 2.9 & 17.8 & 39.60 & 51.62 & 76.71 \\
\hline 5 & 4.06 & 12.8 & 3.97 & 17.5 & 51.97 & 69.48 & 74.80 \\
\hline 6 & 5.14 & 12.7 & 5.04 & 17.2 & 65.28 & 86.69 & 75.30 \\
\hline 7 & 6.5 & 12.2 & 6.45 & 16.8 & 79.30 & 108.36 & 73.18 \\
\hline
\end{tabular}

Data arus dan tegangan merupakan catatan hasil pengamatan, sedangkan daya $\left(\mathrm{P}_{\mathrm{OUT}}\right.$ dan $\left.\mathrm{P}_{\mathrm{IN}}\right)$ dan efisiensi $(\zeta)$ merupakan hasil perhitungan formulasi pada sub bahasan 2.5).

Pengaturan arus keluaran dilakukan dengan menggunakan kombinasi beban lampu halogen $12 \mathrm{~V} / 55 \mathrm{~W}$ dengan dekade resistor, $20 \mathrm{ohm} / 20 \mathrm{~W}$.

Sumber tegangan pengujian diperoleh dengan memparalel 3 buah sumber arus searah masing-masing dengan kemampuan arus 3 ampere. Tegangan sumber ditetapkan dengan besar tegangan 18 volt. Proses pengujian dilakukan dengan mengatur besar arus pada beban secara bertahap, mulai dari 1A hingga mencapai arus $6,5 \mathrm{~A}$.

Pengukuran arus dan tegangan menggunakan alat ukur digital, sehingga pembacaan besaran lebih mudah hingga dua angka dibelakang nol.

\subsection{Pengujian Sistem pada Kondisi Aktual di Lapangan.}

Percobaan pengujian dilakukan dengan merakit sistem lengkap pada kondisi rancangan yang diinginkan. Rangkaian percobaan pengukuran mengacu pada Gambar 9, dengan mengganti sumber daya DC dengan panel sel surya. Pengamatan dilakukan untuk melihat unjuk kerja sistem pada kondisi variasi radiasi matahari secara langsung. Hasil pengamatan ini dilakukan dengan mengambil sample selama 1 jam dengan selang waktu permenit.

Tabel 3 . Percobaan modul sistem pengisian bateri pada kondisi variasi radiasi matahari (1 Jam), (Tegangan awal bateri 12.28 Volt.)

\begin{tabular}{|c|c|c|c|c|c|c|c|c|c|}
\hline \multirow[b]{2}{*}{ No } & \multirow[b]{2}{*}{ Jam } & \multicolumn{4}{|c|}{ pengukuran } & \multicolumn{3}{|c|}{ perhitungan } & \multirow[b]{2}{*}{ Keterangan } \\
\hline & & $V_{1}$ (volt) & $I_{\mathbb{N}}(A)$ & $V_{o}$ (volt) & $\mathrm{I}(\mathrm{A})$ & $\operatorname{Pin}(W)$ & Po(W) & Effisiensi & \\
\hline 1 & 10.5 & 16.1 & 0.18 & 12.28 & 0.119 & 2.898 & 1.46132 & 0.50425 & redup \\
\hline 2 & 10.51 & 18 & 3 & 12.5 & 3.4 & 54 & 42.5 & 0.78704 & cerah \\
\hline 3 & 10.52 & 17.89 & 3 & 12.6 & 3.1 & 53.67 & 39.06 & 0.72778 & \\
\hline 4 & 10.53 & 17.89 & 3 & 12.6 & 3.1 & 53.67 & 39.06 & 0.72778 & \\
\hline 5 & 10.54 & 17.89 & 3 & 12.6 & 3.1 & 53.67 & 39.06 & 0.72778 & \\
\hline 6 & 10.55 & 17.89 & 3 & 12.6 & 3.1 & 53.67 & 39.06 & 0.72778 & \\
\hline 7 & 10.56 & 17.4 & 2.98 & 12.68 & 3 & 51.852 & 38.04 & 0.73363 & \\
\hline 8 & 10.57 & 17.66 & 2.6 & 12.72 & 2.76 & 45.916 & 35.1072 & 0.7646 & \\
\hline 9 & 10.58 & 15.69 & 0.11 & 12.52 & 0.04 & 1.7259 & 0.5008 & 0.29017 & redup \\
\hline 10 & 10.59 & 17.6 & 2.79 & 12.7 & 2.87 & 49.104 & 36.449 & 0.74228 & \\
\hline
\end{tabular}

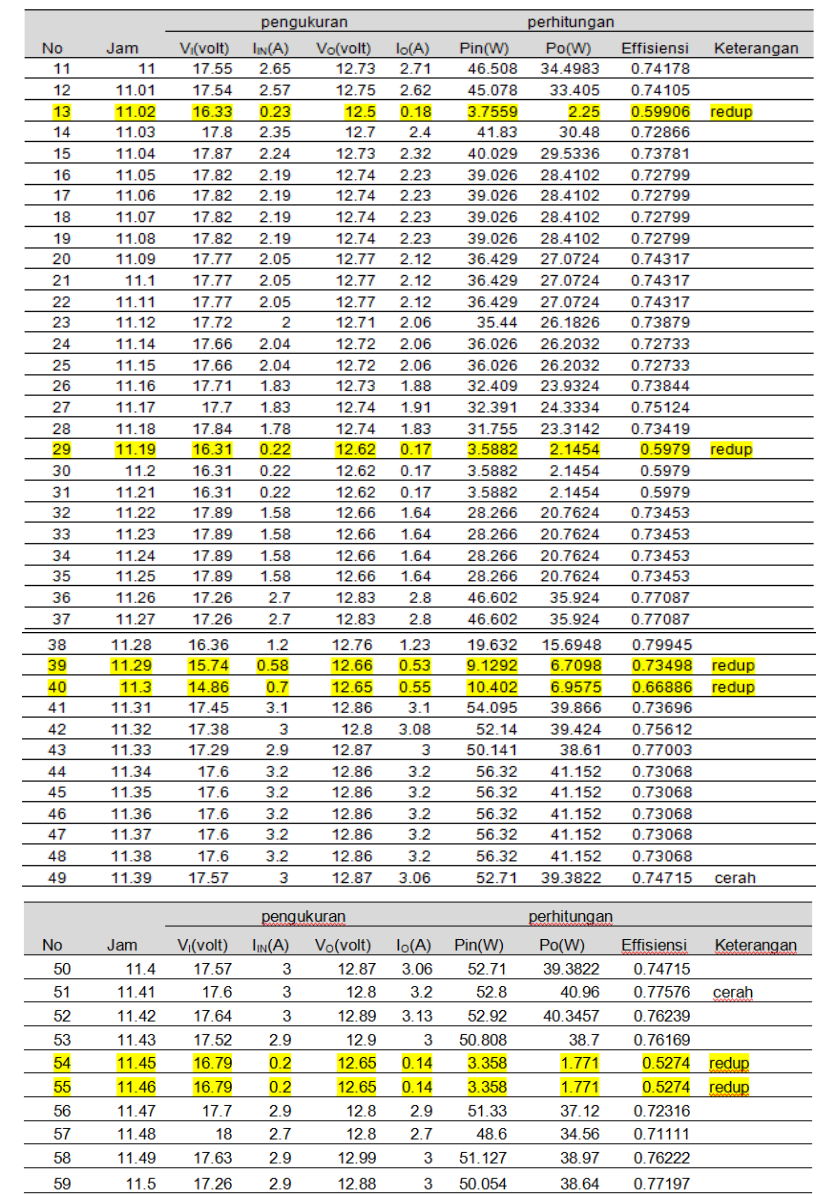

\section{Pembahasan}

Bentuk kurva perolehan dari Tabel 1, memberikan gambaran bahwa pengaturan $\mathrm{D}$, memberikan efek perubahan nilai rata-rata pulsa yang linier atau sebanding dengan perubahan D.

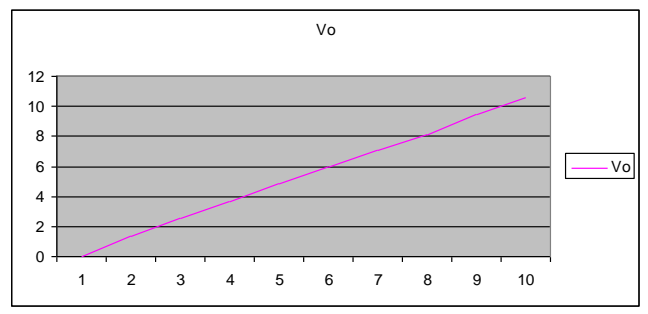

Gambar 18. Karakteristik VO $=[\mathrm{f}(\mathrm{D})]$

Dengan kata lain bahwa jika lebar pulsa membesar akan diikuti dengan kenaikan tegangan rata-rata pulsa itu sendiri, perubahan ini secara teoritis akan mengikuti formulasi yang diberikan oleh, persamaan sebelum nya. 


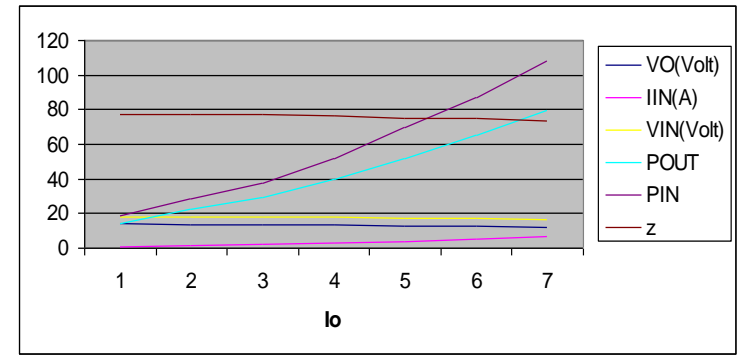

Gambar 19. Karakteristik Berbeban modul sistem pengisian bateri

Plot data dari Tabel 2, memberikan pola perubahan yang spesifik dari tiap-tiap parameter yang diamati. Dengan mengambil acuan perubahan arus keluaran yang semakin besar sebagai perubahan kenaikan beban, maka terlihat bahwa terjadi perubahan juga pada besaran lain sebagai berikut:

- Tegangan keluaran menurun relatif stabil

- Arus masukan makin besar

- Daya keluaran dan masukan mempunyai pola perubahan yang hampir sama

- Efisiensi makin turun

- Rugi daya semakin besar.

- Kerugian daya cukup besar $\zeta \approx 30 \%$,

Pengujian sistem pada kondisi aktual di lapangan dapat diperoleh data seperti pada Tabel 3. Kuat radiasi matahari sangat menentukan daya yang diserap sel surya, dalam hal ini nampak pada kuat arus yang masuk pada sistem. Makin tinggi kuat radiasi sinar matahari, terlihat arus yang keluar dari sel surya makin tinggi dan sebaliknya. Keterangan redup mewakili kondisi terburuk, yang terjadi pada saat awan tebal menghalangi cahaya matahari yang sampai ke permukaan sel surya, dimana arus keluaran sel surya menjadi sangat rendah. Pada saat redup terlihat bahwa antara arus masukan $\mathrm{I}_{\mathrm{IN}}$ dan arus keluaran $\mathrm{I}_{\mathrm{O}}$, mempunyai nilai lebih rendah, tidak sesuai perbandingan seperti saat cerah, dimana arus keluaran lebih besar dari arus masukan, dan sesuai dengan prinsip kerja rangkaian konverter. Dengan mengacu kepada teori superposisi arus searah, maka arus masuk ke bateri dikurangi oleh arus yang di konsumsi oleh rangkaian (lihat arah arus $\mathrm{I}_{\mathrm{C}}$ dan $\mathrm{I}_{\mathrm{O}}$ pada rangkaian gambar 9). Nilai arus ke rangkaian elektronika kendali MPPT cenderung konstan, dengan posisi pemasangan alat ukur arus ke masukan bateri akan diperoleh total arus, jika arus dari sel surya/ konverter $\mathrm{I}_{\mathrm{O}}<\mathrm{I}_{\mathrm{C}}$, maka akan diperoleh nilai arus negatif dan sebaliknya jika $I_{O}>I_{C}$ akan diperoleh nilai arus positif.

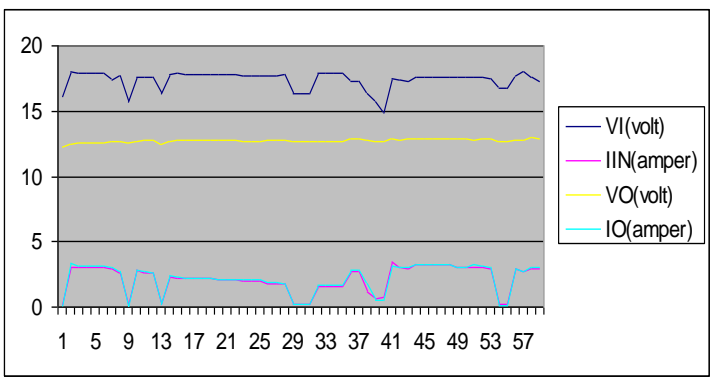

Gambar 20. Karakteristik kuat arus dan besar tegangan yang bervariasi menurut intensitas radiasi matahari dalam pengujian selama 1 jam

Dari Tabel 3 bahwa arus yang masuk ke bateri akan semakin tinggi dengan makin tingginya kuat radiasi matahari. Arus yang masuk ke baterai sangat dipengaruhi oleh prosentase muatan yang masih tersisa dari bateri.

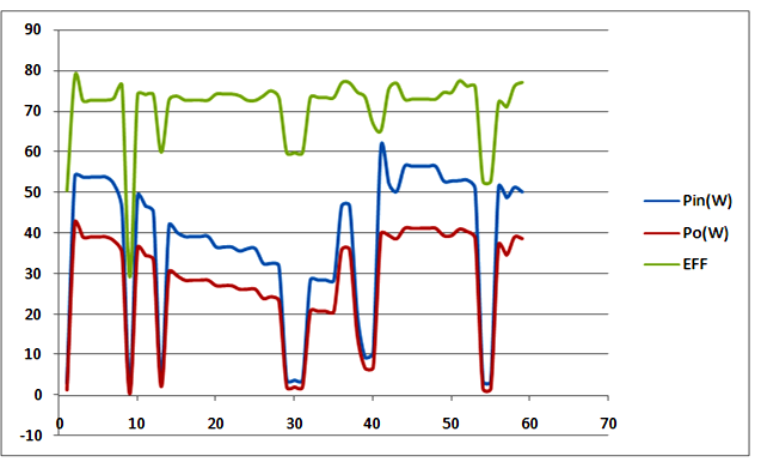

Gambaar 21. Besar daya yang terserap oleh sel surya. (Hasil perhitungan berdasarkan data pada Tabel 3)

\section{Kesimpulan}

- Teknik MPPT P\&O yang diimplementasikan pada prototipe sistem elektronika konverter daya, yang bertujuan memaksimalkan perolehan daya dari sel surya ke beban /bateri, dapat bekerja dengan baik.

- Rangkaian terintegrasi multiplier analog MC 1495 sebagai pengali tegangan dan arus dari sel surya, dapat beroperasi dengan baik sebagai rangkaian utama yang dapat mendeteksi potensi daya yang berasal dari sel surya.

- Hasil rancangan sistem pengisian baterai yang menggunakan komponen lokal dapat bekerja dengan cukup baik.

- Pengunaan IC PWM SG 3524, memenuhi keperluan untk mengendalikan transistor daya pada frekuensi operasi yang direncanakan.

- Penggunaan heatsink pada transisitor daya konverter, sangat diperlukan untuk menjaga agar tetap beroperasi pada temperatur kerja yang aman untuk menghindari bahaya panas yang berlebihan, yang dapat menyebabkan kerusakan sekunder transistor. 


\section{Referensi}

[1] An Introduction to Charge Controllers https://www.whole sale solar.com /solar- information /charge - controller-article

[2] Joe-Air Jiang,Tsong-Liang Huang, Ying-Tung Hsiao and Chia-Hong Chen, "Maximum Power Tracking for Photovoltaic Power Systems", Tamkang Journal of Science and Engineering, Vol. 8, No 2, pp. 147_153 (2005)

[3] Srdjan Srdic, Zoran Radakovic dan Vojinovic Vladimir , Implementation of the Incremental Conductance MPPT Algorithm for Photovoltaic Systems", IX Simposium Industrial Elektronics INDEL 2012, Banja Luka page.34-39,November 2012.

[4] Yen-Jung Mark Tung, Dr. Aiguo Patrick Hu, Dr. Nirmal-Kumar Nair, "Evaluation of Micro Controller Based Maximum Power Point Tracking Methods Using dSPACE Platform", Australian University Power Engineering Conference 2006.

[5] Surawdhaniwar Sonali and Diwan Ritesh. Mr, "Study of Maximum Power Point Tracking Using Perturb and Observe Method ",International Journal of Advanced Research in Computer Engineering \& Technology ISSN: 2278 - 1323,Volume 1, Issue 5, July 2012

[6] Wideband Linear Four_Quadrant Multiplier MC 1495, ON semiconductor Website: http://onsemi.com,

[7] LM2524D/LM3524D Regulating Pulse Width Modulator, National semiconductor corporation, May 2008, http://www.national.com.

[8] [8] AN604 Application note Calculation of conduction losses in a power rectifier, Doc ID 3607 Rev 3, August 2011,

http://www.st.com/resource/en/application_note/cd0000 3894.pdf

[9] D r. D u š a n G r a o v a c , M a r c o P ü r s c h e 1 ,Andreas Kiep, MOSFET Power Losses Calculation Using the Data- Sheet Parameters, Application Note, V 1. 1 , July 2006 ,

[10] Robert W. Erickson, Fundamentals of Power Electronics, Chapter 4.Switch Realization, University of Colorado, Boulder

http://ecee.colorado.edu/copec/book/slides/Ch4slide.pdf

[11] BU-403: Charging Lead Acid http: //battery university.com /learn/ article/ charging_the_lead_acid_battery

[12] D. P. Hohm and M. E. Ropp, "Comparative Study of Maximum Power Point Tracking Algorithms," Progress in Photovoltaics: Research and Applications, vol. 11, issue 1, pp.47-62, Jan. 2003

[13] Rashid H Muhammad, Ph.D. Power Electronics Handbook, Academic Press, 2001,

[14] IRF 9540,RF 19540SM Rev. B, Data sheet, Fairchild Semiconductor Corporation, 2002.

[15] http://www.electronics- tutorials.ws/ transistor/ tran_2.html

\section{Biografi}

Rianda , dilahirkan di Ketapang, Indonesia, pada tahun 1965. Menyelesaikan pendidikan D-3 Teknik Elektro di Politeknik ITB tahun 1988, S-1 Teknik elektro di Fakultas Teknik Universitas Tanjungpura pontianak tahun 2000 dan S-2 teknik Elektro di Universitas Tanjungpura di pontianak tahun 2017. Sejak tahun 1990 hingga sekarang sebagai tenaga Pengajar di Politeknik Negeri Pontianak. 